\title{
Effects of cadmium on lipids of almond seedlings (Prunus dulcis)
}

Nada Elloumi ${ }^{*}$, Mohamed Zouari ${ }^{2}$, Leila Chaari ${ }^{3}$, Chiraz Jomni ${ }^{2}$, Brahim Marzouk ${ }^{4}$ and Ferjani Ben Abdallah ${ }^{2}$

\begin{abstract}
Background: Cadmium uptake and distribution, as well as its effects on lipid composition was investigated in almond seedlings (Prunus dulcis) grown in culture solution supplied with two concentrations of Cd (50 and $150 \mu \mathrm{M}$ ).

Results: The accumulation of $\mathrm{Cd}$ increased with external metal concentrations, and was considerably higher in roots than in leaves. Fourteen days after $\mathrm{Cd}$ treatment, the membrane lipids were extracted and separated on silica-gel thin layer chromatography (TLC). Fatty acid methyl esters were analyzed by FID-GC on a capillary column. Our results showed that $\mathrm{Cd}$ stress decreased the quantities of all lipids classes (phospholipids, galactolipids and neutral lipids). Galactolipid, phospholipid and neutral lipid concentrations decreased more in roots than in leaves by Cd-treatment. In almost all lipid classes the proportion of palmitic acid (16:0), linoleic (18: 2) and that of linolenic (18: 3) acid decreased, suggesting that heavy metal treatment induced an alteration in the fatty acid synthesis processes.
\end{abstract}

Conclusions: In conclusion, our results show that the changes found in total fatty acids, in the quantities of all lipids classes, and in the in the profiles of individual polar lipids suggest that membrane structure and function might be altered by $\mathrm{Cd}$ stress.

Keywords: Cadmium; Galactolipids; Lipid composition; Neutral lipids; Phospholipids; Prunus dulcis

\section{Background}

Contamination of the soil by heavy metals is a serious environmental problem with potentially harmful consequences to agriculture (Di Toppi and Gabbrielli 1999; Robinson et al. 2001; Certı et al. 2005). In most plant species, heavy metals have been shown to affect a wide range of plant cellular activities, such as mineral distribution (Shukla et al. 2003; Ben Ammar et al. 2005; Elloumi et al. 2007), sugar metabolism (Elloumi et al. 2007), sulphate assimilation (Nussbaum et al. 1988), photosynthetic processes (Krantev et al. 2008; Velikova et al. 2011), plant growth (Das et al. 1997) and several enzyme activities (Schützendübel et al. 2001; Sobkowiak et al. 2004). Some of these effects are mediated through a general action on the membrane structure, resulting from an alteration in lipid composition. Hall (2002) showed that plant membrane structure may be considered as the first target for heavy metal toxicity. Although

\footnotetext{
* Correspondence: nadaelloumi@yahoo.fr

'Laboratory of Water, Energy and Environment, Sfax University, Higher

Institute of Biotechnology of Sfax, Sfax, Tunisia

Full list of author information is available at the end of the article
}

different plant species and varieties can be affected by high amounts of heavy metals, some species are tolerant to lower levels. To avoid heavy metals toxicity, the plants adopt various defense strategies including internal metal detoxification processes which may be achieved through both cellular and subcellular compartmentation or complexation with cellular ligands such as phytochelatins (Cobbett and Goldsbrough 2002; Ma et al. 2005). It appears that cell decompartmentalization and modification of membrane functions represent the first targets for metal toxicity (Meharg 1993; Ouariti et al. 1997; Nouairi et al. 2006a). To evaluate this, we need to know to what extent metal can result changes in fatty acid composition of the major lipids of the cell membranes. Changes in the composition of fatty acids which affect the structural and functional properties of cell membranes are important in the acclimation of most types of plants (Martin et al. 1976). Previous work showed that the ratio of unsaturated to saturated fatty acids play an important role in determining the physiological function of the plant tissue (Brenner 1984; Certık et al. 2005). Lipid molecules are essential building blocks for every membrane of a living cell. 
Membranes are sites for many specific enzymatic activities, transport ions and metabolites, and hormonal receptors. The composition of membrane lipids may be a factor in determining major biological properties of membranes that may influence biological changes of plants (Certık et al. 2005).

There is little information in the literature about the effects of heavy metals on membrane lipid metabolism. Most of the studies have been conducted to evaluate lipid peroxidation (Chaoui et al. 1997; Attila et al. 2004; Elloumi et al. 2007) and fatty acid composition in isolated chloroplasts of stressed plants (Vassilev et al. 2004).

The aim of the present work was to assess how Cd stress affects the composition and biosynthesis of lipids and fatty acids in almond leaves and roots, accompanying the accumulation of this heavy metal in almond seedlings.

\section{Methods}

\section{Plant culture}

Seeds of Prunus dulcis were germinated on wet filter paper, in the darkness at $4^{\circ} \mathrm{C}$ for $15-20$ days. Following their germination, seedlings having approximately the same size were transferred to a Long Ashton nutrient solution (Hewitt 1966) that was continuously aerated and weekly renewed. Seedlings were cultivated in a growth chamber under the following conditions: $22 / 26^{\circ} \mathrm{C}$ day/ night temperature, $16 / 8$ photoperiod and $300 \mu \mathrm{mol} \mathrm{m} \mathrm{m}^{-2}$ $\mathrm{s}^{-1}$ light intensity. After a 2 -week acclimatization phase, 50 and $150 \mu \mathrm{M} \mathrm{CdCl}$ were added to the nutrient medium. On the 14th day from the start of Cd supply, eight plants from each treatment were harvested. Leaves, stems and roots were separated.

The roots seedlings were washed first with $20 \mathrm{mM}$ $\mathrm{Na}_{2}$-EDTA for about $10 \mathrm{~min}$ in order to remove excess $\mathrm{Cd}$ adhering to the surfaces and finally washed with deionized water.

Dry matter of different organ tissues was determined after drying in an oven at $80^{\circ} \mathrm{C}$ for $48 \mathrm{~h}$.

Dried samples were then ground and reduced to fine powder.

\section{Cadmium analysis}

Ground samples were digested in a nitric and perchloric acid mixture $(2: 1 \mathrm{v} / \mathrm{v})$. Cadmium was determined by atomic absorption spectrophotometry with polarized Zeeman (HITACHI; Z-6100).

\section{Lipid extraction and separation}

Total lipids from leaves and roots were extracted using the method described by Bligh and Dyer (1959). One gramme of fresh material was fixed by boiling water for $5 \mathrm{~min}$, in order to inactivate the phospholipases. Samples were ground manually in a mortar into a mixture of chloroform/methanol (2:1, v/v). After washing with water of fixation and decantation at $4^{\circ} \mathrm{C}$, two phases were obtained. Then the organic phase containing total lipids was recovered and dried under a nitrogen stream. Finally, the residue was dissolved in a known volume of toluene-ethanol $(4: 1, \mathrm{v} / \mathrm{v})$ and stored at $-20^{\circ} \mathrm{C}$ for further analyses.

\section{Lipid analysis}

PL, GL and neutral lipids (NL) were separated by TLC on silica gel plates 60 (Merck) with the following solvent mixtures: chloroform:acetone:.methanol:acetic acid:water (50:20:10:10:5, v/v) (Lepage 1967). After development, bands were located with iodine vapours or spraying the plates with $0.1 \%$ Rhodamine $6 \mathrm{G}$ in ethanol. Individual lipids were identified by comparison with lipid standards and scraped from the TLC plates. The samples were quantified against a heptadecanoic acid (17:0) internal standard, and the amount of each lipid species in the sample could, therefore, be expressed both as an absolute amount in the $0.1 \mathrm{~g}$ samples, and as a percentage of the total lipid present in the sample.

Fatty acids from total lipids and lipid classes were transformed into their corresponding methyl esters as described by Cecchi et al. (1985). Transmethylation was made by the addition of $2 \mathrm{ml}$ of hexane, $0.5 \mathrm{ml}$ of $3 \%$ sodium methylate, a known amount of the internal standard heptadecanoic acid methyl ester (C17:0), $0.2 \mathrm{ml}$ of 1 $\mathrm{NH}_{2} \mathrm{SO}_{4}$ and $1.5 \mathrm{ml}$ of $10 \%$ sodium chloride. The hexanic phase containing fatty acid methyl esters (FAME) was recovered and its volume was reduced in a stream of nitrogen, prior to analysis.

GC analyses were performed using a Hewlett-Packard 6890 gas chromatograph equipped with a flame ionization detector (FID) and an electronic pressure control (EPC) injector. A polar HP Innowax (PEG) column (30 m $\times$ $0.25 \mathrm{~mm}, 0.25 \mu \mathrm{m}$ film thickness) was used. The carrier gas was $\mathrm{N}_{2}$ with a flow rate of $1.6 \mathrm{ml} / \mathrm{min}$. The split ratio was 60:1. The analyses were performed using the following temperature program: the initial oven temperature was held at $150^{\circ} \mathrm{C}$ for $1 \mathrm{~min}$, increased at a rate of $15^{\circ} \mathrm{C} /$ min to $200^{\circ} \mathrm{C}$, and then was held there for $3 \mathrm{~min}$ and finally ramped at a rate of $2^{\circ} \mathrm{C} / \mathrm{min}$ to $242^{\circ} \mathrm{C}$. The detector and injector temperatures were set at 275 and $250^{\circ} \mathrm{C}$, respectively (Aidi Wannes et al. 2009). Analyses were performed in triplicate. Fatty acid methyl esters were identified by comparison of their retention times to those of pure reference standards.

\section{Statistical analysis}

Microsoft Excel and SPSS 17.0 were used to analyze the data. All measurements were replicated three times. Average values and standard deviations (S.D.) were calculated by Microsoft Office Excel 2007 for all the data in this paper. Duncan's multiple range test was employed 
to compare the changes among different treatments at $p<0.05$ level.

\section{Results}

Almond plants exposed to $\mathrm{Cd}$ in the nutrient solution accumulated substantial amounts of $\mathrm{Cd}$ in the roots and the leaves (Figure 1). At $50 \mu \mathrm{M}$ about $96 \%$ of total plant concentration of $\mathrm{Cd}$ was found in the roots. At $150 \mu \mathrm{M}$, this proportion increased to $98 \%$, thus suggesting that the root is the primary site of $\mathrm{Cd}$ accumulation. Small amounts of $\mathrm{Cd}$, however, were translocated into the leaves.

In control plants, significant differences in the lipid composition of roots and leaves were observed (Table 1). In the leaves, galactolipids were the major constituent lipid classes, accounting for $51 \%$ of the total lipids (Table 1). Moreover, in this lipid class the proportion of monogalactosyl diacylglycerol (MGDG) was higher than that of digalactosyl diacylglycerol (DGDG) (29 and 21\% of total lipids, respectively) (Figure 2). However, root lipids were characterized by a high level of phospholipids, about $64 \%$ of the total lipids, followed by neutral lipids and galactolipids (Table 1). The most abundant phospholipids in both leaf and root tissues were phosphatidylcholine (PC) and phosphatidylglycerol (PG) (Figure 3). It is also important to note that the percentage of DGDG of total root lipids was lower than that of MGDG (1.7 and 2.7\% of total lipids, respectively). Some fatty acid species, palmitic (C16: $0)$, linoleic (C18:2) and linolenic (C18:3) acids were commonly higher in root and leaf lipids, and only differed in their relative proportions (Table 2). The contribution of C18:3 in the leaves was significantly high $(48 \%$ of total fatty acids) and that of C16: 0 and C18:2 were low (14.6 and $13.3 \%$ of total fatty acids, respectively), and vice versa in the root lipids. Also palmitoleic (C16:l), stearic (C18:0) and oleic (C18:l) acids were present. Furthermore, the fatty acid composition of leaf lipids was characterized by the presence of C20: 0, approximately $9.7 \%$ of the total fatty acids (Table 2).
The amount of total lipids, which corresponds to the total fatty acids, was lower in treated plants than in control ones, and was remarkably dependent on metal dose. The results (Tables 1 and 2) indicate a decrease of leaf lipids from $18 \%$ to $63 \%$ of the control with $\mathrm{Cd}$ treatment (Table 2). In roots, there was however a marked drop of total lipids and this ranged from 27 to $74 \%$ of the control with $\mathrm{Cd}$ treatments (Table 1). In leaves, the fatty acids most subject to variation were stearic (C18:0) acids (Table 2). However, in roots the remarkable impoverishment of 18: 2 was accompanied by enrichment of C16:0, C18:0 and C18:3.

The data in Table 1 reveal that the decline of total lipid concentration in treated seedlings was associated with a shift towards a low concentration of all lipid classes. Also, there were substantial differences in the effect of $\mathrm{Cd}$ on lipid classes isolated from leaves and roots of stressed plants. Indeed, the galactolipid concentration was more reduced in roots ( $74 \%$ of control) than in leaves (63\% of control) by toxic Cd-treatment (Table 1). An important decrease of MGDG concentration (74\% of control) and DGDG concentration (73\% of control) was observed in metal stressed-almond leaves and roots. The MGDG/DGDG ratio remained, remarkably, unchanged in roots and in leaves (1.9) (Figure 2). Beside, the decrease in phospholipid concentration by $\mathrm{Cd}$ treatment was more pronounced in roots than in leaves; and this resulted in a decline of the concentration of all phospholipid molecules including phosphatidylcholine (PC), phosphatidylglycerol (PG), phosphatidylethanolamine (PE), phosphatidylinositol (PI) and phosphatidic acid (PA) (Figure 3).

The variation in neutral lipid content was also similar to that of the phospholipids. The changes in fatty acid composition due to heavy metal-stress differed from individual lipids as well as organs (Tables 3 and 4). Therefore, the fatty acids composition of galactolipids changed by $\mathrm{Cd}$ treatment. In fact, within MGDG of treated leaves the drop of $\mathrm{C} 18: 3$ concentration results in an increase of C16:0
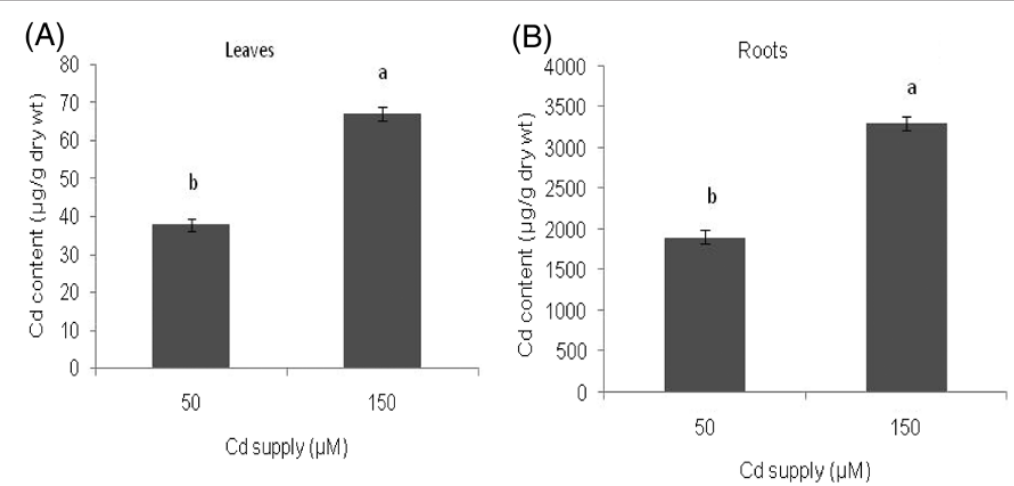

Figure 1 Cadmium content in leaves (A) and roots (B) of almond seedlings after 14 days of exposure to two concentrations of cadmium. The error bars indicate mean \pm SE $(n=3)$. Means with different letters indicate a significant difference at $P<0.05$ using Duncan multiple range test. 
Table 1 Lipid concentration ( $\mathrm{mg} \mathrm{g}^{-1}$ dry wt) of leaves and roots of almond seedlings exposed to two concentrations of cadmium

\begin{tabular}{lllll}
\hline Treatments & Galactolipids & Phospholipids & Neutral lipids & Totals lipids \\
\hline & & Leaves & & \\
Control & $19.89 \pm 3.22 \mathrm{a}$ & $13.30 \pm 1.26 \mathrm{a}$ & $5.65 \pm 0.55 \mathrm{a}$ & $38.84 \pm 2.22 \mathrm{a}$ \\
Cd 50 & $12.06 \pm 0.84 \mathrm{~b}$ & $5.54 \pm 0.19 \mathrm{~b}$ & $3.93 \pm 0.37 \mathrm{~b}$ & $31.52 \pm 0.30 \mathrm{~b}$ \\
Cd 150 & $7.28 \pm 1.02 \mathrm{c}$ & $5.77 \pm 0.36 \mathrm{~b}$ & $4.27 \pm 0.23 \mathrm{~b}$ & $14.27 \pm 1.13 \mathrm{c}$ \\
& & Roots & & \\
Control & $2.79 \pm 0.045 \mathrm{a}$ & $15.45 \pm 0.096 \mathrm{a}$ & $6.01 \pm 0.003 \mathrm{a}$ & $24.25 \pm 3.89 \mathrm{a}$ \\
Cd 50 & $1.59 \pm 0.154 \mathrm{~b}$ & $8.46 \pm 0.37 \mathrm{~b}$ & $3.36 \pm 0.058 \mathrm{~b}$ & $17.78 \pm 2.86 \mathrm{~b}$ \\
Cd 150 & $0.75 \pm 0.0036 \mathrm{c}$ & $4.59 \pm 0.002 \mathrm{c}$ & $2.10 \pm 0.041 \mathrm{c}$ & $6.26 \pm 2.24 \mathrm{c}$ \\
\hline
\end{tabular}

Means with different letters indicate a significant difference at $\mathrm{P}<0.05$ using Duncan multiple range test.

percentages (Table 4). Whereas, whithin the MGDG of treated roots the drop of $\mathrm{C} 18: 1$ and $\mathrm{C} 18: 2$ concentrations results in an increase of $\mathrm{C} 18: 3$ percentages. Further, within DGDG of treated roots the drop of C18:1concentration results in an increase of C18:3, C18:0, C16:1 and C16:0 percentages. In neutral lipids, the decrease of C20:0 and C18:1 percentages was accompanied with an augmentation of C18:3 and C18:2 in leaves. However, in roots the decrease of C18:1 percentage was accompanied with an augmentation of C18:3, C18:2 and C18:0. The fatty acid composition of phospholipids also changed by heavy metal-stress. Therefore, within both PC and PG of leaves the high $\mathrm{Cd}$ concentration resulted in a decrease of $\mathrm{C} 18: 1$ and $\mathrm{C} 18: 3$ proportions with an increase of C18:0. But in PG of stressed roots, the sharp decline of $\mathrm{C} 16: 0$ and $\mathrm{C} 18: 2$ percentages was coupled with an increase of C18:0 and C18:1 fatty acids. Moreover, within PC of treated roots we noted an increase only in that of saturated ones, particularly of C18:0 and C16:0. Although in phospholipid classes of leaves the changes of fatty acid composition were somewhat different from those of roots, our data generally indicate that the toxic level of the heavy metals used leads to a decrease in concentration of unsaturated fatty acids and to an increase in that of saturated ones.

\section{Discussion}

The distribution of $\mathrm{Cd}$ in the plant tissues (root and Leaf) indicated that $90 \%$ of the Cd was retained in roots and only a small proportion, was translocated to aerial parts. The retention of high amounts of $\mathrm{Cd}$ in the roots is a typical response of several plants (Verkleij and Schat 1990; Mohamed et al. 2012). This is an important factor, since the differential accumulation of $\mathrm{Cd}$ between leaves and roots might explain the lower damage of lipid metabolism in the above ground parts of stressed almond plants. On the other hand, the excess of absorbed metals in roots can be pumped largely into intracellular compartments, resulting to a high metal concentration in the biochemically active compartments. This confirms furthermore the marked damage recorded in the root systems.

Our results show a significant decrease of the amount of total lipids, which corresponds to total fatty acids, as $\mathrm{Cd}$ concentration of the treatment medium increases. This decrease is more pronounced in root lipids than in
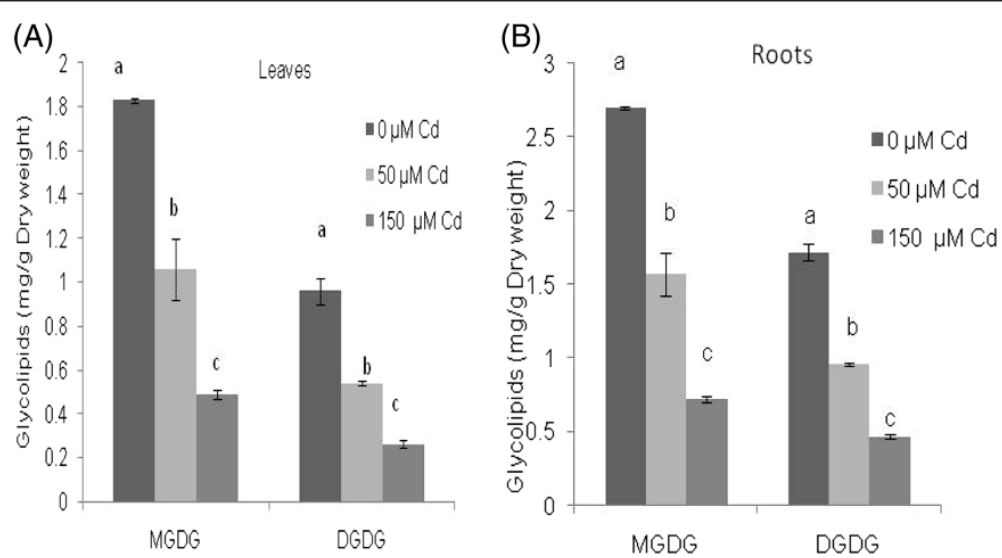

Figure 2 Galactolipids classes of leaves (A) and roots (B) of almond seedlings exposed to two concentrations of cadmium. The error bars indicate mean \pm SE $(n=3)$. Means with different letters for each galactolipid class indicate a significant difference at $P<0.05$ using Duncan multiple range test. 

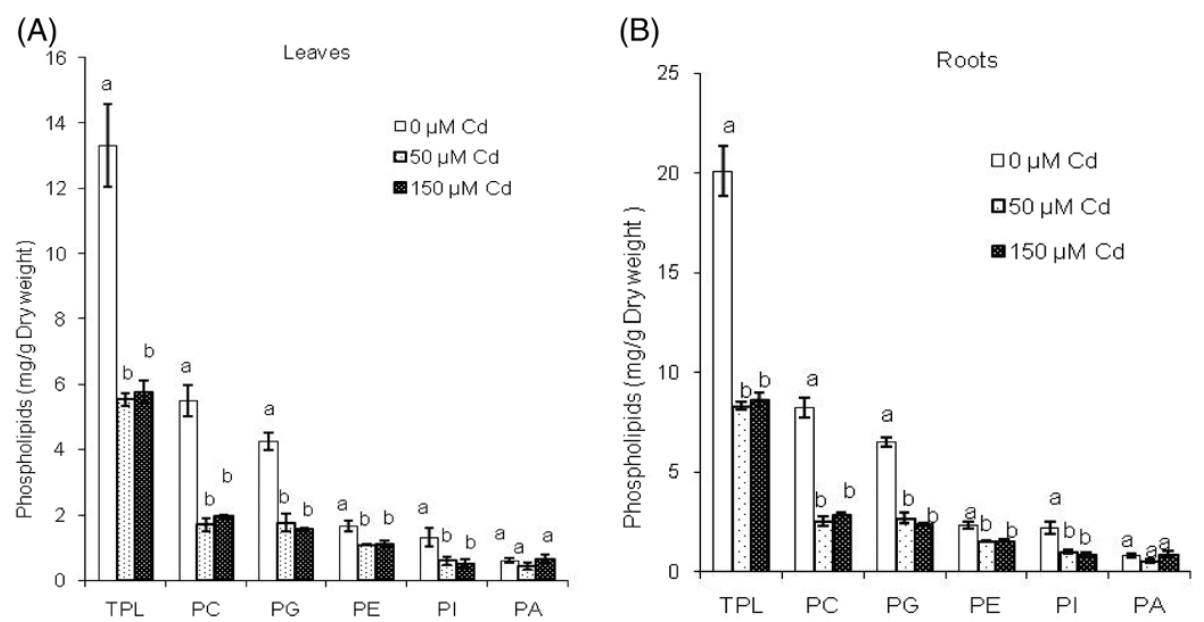

Figure 3 Phospholipid classes of leaves (A) and roots (B) of almond seedlings exposed to two concentrations of cadmium. The error bars indicate mean \pm SE $(n=3)$. Means with different letters for each phospholipid class indicate a significant difference at $P<0.05$ using Duncan multiple range test. TPL, total phospholipids; PC, phosphatidylcholine; PG, phosphatidylglycerol; PE, phosphatidylethanolamine; $\mathrm{PI}$, phosphatidylinositol; PA, phosphatidic acid.

leaf. In leaves of plants treated with the high $\mathrm{Cd}$ dose, only the percentage of C18: 0 increased. However, in roots a remarkable impoverishment of $\mathrm{C} 18: 2$ was accompanied with an enrichment of C18:3, C18:0, C16:0. Also, it should be noted that in roots, excess Cd had a strong effect on total lipid concentration and fatty acid composition. In previous studies (Verdoni et al. 2001; Le Guédard et al. 2008) carried out with lettuce and tomato seedlings in a controlled environment, we showed that

Table 2 Total fatty acid composition of leaves and roots of almond seedlings exposed to two concentrations of cadmium

\begin{tabular}{llll}
\hline \multicolumn{4}{c}{ Treatments } \\
\cline { 2 - 4 } C & Cd50 & Cd150 \\
\hline Fatty acid of leaves (\% of total) & & $13.9 \mathrm{a}$ \\
C16:0 & $14.6 \mathrm{a}$ & $13.4 \mathrm{a}$ & $1.9 \mathrm{a}$ \\
C16:1 & $1.6 \mathrm{a}$ & $1.4 \mathrm{a}$ & $3.6 \mathrm{a}$ \\
C18:0 & $2.1 \mathrm{~b}$ & $3.4 \mathrm{a}$ & $9 \mathrm{a}$ \\
C18:1 & $10.3 \mathrm{a}$ & $10 \mathrm{a}$ & $14.3 \mathrm{a}$ \\
C18:2 & $13.3 \mathrm{a}$ & $16.7 \mathrm{a}$ & $48.3 \mathrm{a}$ \\
C18:3 & $48.4 \mathrm{a}$ & $46.3 \mathrm{a}$ & $9 \mathrm{a}$ \\
C20:0 & $9.7 \mathrm{a}$ & $8.8 \mathrm{a}$ & \\
Fatty acid of roots $(\%$ of total) & & $27.1 \mathrm{a}$ \\
C16:0 & $23.4 \mathrm{~b}$ & $22.0 \mathrm{~b}$ & $8.3 \mathrm{a}$ \\
C18:0 & $7.1 \mathrm{~b}$ & $9.3 \mathrm{a}$ & $8.3 \mathrm{~b}$ \\
C18:1 & $10.3 \mathrm{~b}$ & $16.7 \mathrm{a}$ & $32.4 \mathrm{~b}$ \\
C18:2 & $40.0 \mathrm{a}$ & $33.5 \mathrm{~b}$ & $23.9 \mathrm{a}$ \\
C18:3 & $19.2 \mathrm{~b}$ & $18.5 \mathrm{~b}$ & \\
\hline
\end{tabular}

Means with different letters indicate a significant difference at $\mathrm{P}<0.05$ using Duncan multiple range test. the percentage of tri-unsaturated fatty acids in leaves decreased while the percentage of $\mathrm{C} 18: 2$, and to a lesser extent $\mathrm{C} 18: 1$ and $\mathrm{C} 18: 0$, increased, when plants were grown for $14 \mathrm{~d}$ on metal-contaminated soils. Hence, we proposed that the leaf fatty acid composition, and more precisely the $\mathrm{C} 18: 3 /(\mathrm{C} 18: 0+\mathrm{C} 18: 1+\mathrm{C} 18: 2)$ ratio could be used as an indicator of metal bioavailability and of their adverse effects on plants. In accordance with these results, a decrease of the percentage of $\mathrm{C} 18: 3$ and an increase of the percentage of the other 18 -carbon fatty acids were also observed in leaves of Brassica napus and Capsicum annum seedlings grown in hydroponic solutions supplied with $\mathrm{CdCl}_{2}$ (Jemal et al. 2000; Ben Youssef et al. 2005). Similar results were observed in leaves of tomato grown in solutions containing copper or cadmium (Ouariti et al. 1997; Djebali et al. 2005).

Galactolipids and phospholipids are essential constituents to all biomembranes. Monogalactosyl diglyceride (MGDG) and digalactosyl diglyceride (DGDG) were the major galactolipids in chloroplast thylakoid (Williams et al. 1983) and primarily occurred in almond leaves. The most abundant phospholipids in almond leaves and roots were phosphatidylcholine (PC) and phosphatidylglycerol (PG). Changes occurring in the lipid composition of these membranes will certainly modify their permeability, energy transduction capacity, and the activities of membranebound enzymes (Wang and Lin 2006). Palmitic (C16:0), stearic (C18:0), oleic (C18:1), linoleic (C18:2), and linolenic (C18:3) acids occurred in galacto- and phospholipids in the almond leaf and root tissue membranes. Palmitic, linoleic, and a-linolenic were the predominant fatty acids in almond. In different tissues (leaves and roots), their proportions of fatty acids were different. 
Table 3 Fatty acid composition of galactolipids, neutral lipids and phospholipids in roots of almond seedlings after exposure to two concentrations of cadmium

\begin{tabular}{|c|c|c|c|c|c|c|c|c|}
\hline \multirow{2}{*}{$\begin{array}{l}\text { Acyl } \\
\text { Lipids }\end{array}$} & \multirow[b]{2}{*}{ Treatment } & \multicolumn{6}{|c|}{ Fatty acid composition (\% of total) } & \multirow[b]{2}{*}{ Unsaturation } \\
\hline & & C16:0 & C16:1 & C18:0 & C18:1 & C18:2 & C18:3 & \\
\hline \multirow[t]{3}{*}{$\overline{M G D G}$} & 0 & $22.8 a$ & $2.8 \mathrm{~b}$ & $8.5 a$ & $20.6 a$ & $31.6 a$ & 13. $7 b$ & 68.7 \\
\hline & 50 & $21.5 a$ & $4.3 a$ & $5.4 a$ & $13.0 \mathrm{~b}$ & $27.2 b$ & $28.6 a$ & 73.1 \\
\hline & 150 & $22.7 a$ & $6.3 a$ & $9.1 \mathrm{a}$ & $11.7 \mathrm{~b}$ & $19.8 \mathrm{C}$ & $30.4 a$ & 68.2 \\
\hline \multirow[t]{3}{*}{ DGDG } & 0 & $26.4 b$ & $3.4 \mathrm{~b}$ & $11.5 b$ & $21.1 \mathrm{a}$ & $31.6 a$ & $6.0 \mathrm{~b}$ & 62.1 \\
\hline & 50 & $28.5 b$ & $3.9 \mathrm{~b}$ & $14.7 a$ & $13.8 \mathrm{~b}$ & $33.1 \mathrm{a}$ & $6.0 \mathrm{~b}$ & 56.8 \\
\hline & 150 & $31.1 \mathrm{a}$ & $5.5 a$ & $13.9 \mathrm{a}$ & $10.2 b$ & $27.3 b$ & $12.0 \mathrm{a}$ & 55 \\
\hline \multirow[t]{3}{*}{ PC } & 0 & $28.7 b$ & $1.7 \mathrm{a}$ & $8.8 b$ & $9.1 a$ & $39.2 \mathrm{a}$ & $12.4 a$ & 66.6 \\
\hline & 50 & $33.6 a$ & $1.7 \mathrm{a}$ & $7.9 b$ & $9.4 a$ & $33.6 b$ & 13.9a & 47.6 \\
\hline & 150 & $32.3 a$ & $1.1 \mathrm{a}$ & $12.4 a$ & $7.1 \mathrm{a}$ & $32.8 b$ & 14.3a & 47.1 \\
\hline \multirow[t]{3}{*}{ PG } & 0 & $67.3 a$ & $5.2 \mathrm{a}$ & $7.6 \mathrm{c}$ & $7.9 c$ & $9.2 \mathrm{~b}$ & $2.8 \mathrm{a}$ & 53.6 \\
\hline & 50 & $60.8 b$ & $5.6 a$ & $9.5 b$ & $10.8 \mathrm{~b}$ & 10.0a & $3.3 a$ & 41.1 \\
\hline & 150 & $59.4 b$ & $5.3 a$ & 13.7a & 9.8a & $8.7 c$ & $3.1 \mathrm{a}$ & 49.0 \\
\hline \multirow[t]{3}{*}{ LN } & 0 & $35.5 a$ & $7.6 a$ & $6.6 c$ & $22.4 a$ & $24.0 \mathrm{~b}$ & $3.9 b$ & 57.9 \\
\hline & 50 & $28.2 b$ & $8.6 a$ & $9.2 \mathrm{~b}$ & $18.3 b$ & $28.4 a$ & $7.2 \mathrm{a}$ & 62.5 \\
\hline & 150 & $26.8 \mathrm{~b}$ & $9.3 a$ & $11.5 \mathrm{a}$ & $19.4 b$ & 27.3a & $5.7 a$ & 61.7 \\
\hline
\end{tabular}

Means with different letters for each lipid class indicate a significant difference at $\mathrm{P}<0.05$ using Duncan multiple range test.

In fact, under cadmium treatment we noted a significant decrease of lipid concentration and marked alterations of fatty acid composition in all lipid classes. A same decrease of MGDG and DGDG was observed in cadmium stressedalmond leaves and roots, resulting in unaffected MGDG/ DGDG ratio. The decrease in galactolipids observed in this study can be interpreted to show alterations of photosynthetic membranes. The decrease in MGDG and DGDG indicated that cadmium could affect the photosynthesis, since the structure of chloroplastic membranes could be affected. Many studies have reported that the ratio of MGDG/DGDG was adversely affected in plants

Table 4 Fatty acid composition of galactolipids, neutral lipids and phospholipids in leaves of almond seedlings after exposure to two concentrations of cadmium

\begin{tabular}{|c|c|c|c|c|c|c|c|c|c|}
\hline \multirow{2}{*}{$\begin{array}{l}\text { Acyl } \\
\text { Lipids }\end{array}$} & \multirow[b]{2}{*}{ Treatment } & \multicolumn{6}{|c|}{ Fatty acid composition (\% of total) } & \multirow[b]{2}{*}{$\mathrm{C} 20: 0$} & \multirow[b]{2}{*}{ Unsaturation } \\
\hline & & C16:0 & C16:1 & C18:0 & C18:1 & C18:2 & C18:3 & & \\
\hline \multirow[t]{3}{*}{$\overline{M G D G}$} & 0 & $4.5 b$ & & $2.0 \mathrm{a}$ & $7.5 a$ & $15.6 a$ & $70.4 a$ & & 93.5 \\
\hline & 50 & $7.3 a$ & & $2.6 a$ & $9.9 a$ & $15.4 a$ & $64.8 \mathrm{~b}$ & & 90.1 \\
\hline & 150 & $6.8 a$ & & $2.8 \mathrm{a}$ & $8.9 a$ & $12.4 \mathrm{a}$ & $69.1 b$ & & 93.4 \\
\hline \multirow[t]{3}{*}{ DGDG } & 0 & $31.3 b$ & & $4.4 a$ & $3.1 \mathrm{a}$ & $10.8 \mathrm{a}$ & $50.4 a$ & & 64.3 \\
\hline & 50 & $30.1 b$ & & $6.6 a$ & $2.7 a$ & $6.7 b$ & $53.9 a$ & & 63.3 \\
\hline & 150 & $40.1 \mathrm{a}$ & & $5.6 a$ & $2.8 a$ & $8.5 b$ & $43.0 \mathrm{~b}$ & & 54.3 \\
\hline \multirow[t]{3}{*}{ PC } & 0 & $25.6 b$ & & $7.8 \mathrm{~b}$ & $35.1 a$ & $18 b$ & $13.5 a$ & & 66.6 \\
\hline & 50 & $37.7 a$ & & $14.7 a$ & $21.2 b$ & $17.2 b$ & $9.2 \mathrm{~b}$ & & 47.6 \\
\hline & 150 & $38.9 a$ & & $14 a$ & $16.6 b$ & $22.5 \mathrm{a}$ & $8 b$ & & 47.1 \\
\hline \multirow[t]{3}{*}{$P G$} & 0 & $44.1 \mathrm{~b}$ & $14.9 \mathrm{~b}$ & $2.3 b$ & $14.1 a$ & $17.2 \mathrm{a}$ & $7.4 a$ & & 53.6 \\
\hline & 50 & $56.0 \mathrm{a}$ & 19.9ab & $2.9 \mathrm{~b}$ & $8.4 b$ & $8.5 b$ & $4.2 \mathrm{~b}$ & & 41 \\
\hline & 150 & $44.3 b$ & 23.1a & $6.7 a$ & $8.6 \mathrm{~b}$ & $11.7 \mathrm{~b}$ & $5.6 b$ & & 49 \\
\hline \multirow[t]{3}{*}{ LN } & 0 & $27.9 b$ & $8.1 a$ & $2.8 \mathrm{a}$ & $8.3 a$ & $6.3 b$ & $3.2 b$ & $43.4 \mathrm{a}$ & 25.9 \\
\hline & 50 & $30.9 a$ & $8.5 a$ & $3.2 \mathrm{a}$ & 7.1a & $5.5 b$ & $6.3 a$ & $38.5 b$ & 27.4 \\
\hline & 150 & $29.9 a$ & $6.7 a$ & $3.7 a$ & $6.7 \mathrm{a}$ & $9.9 a$ & $6.1 a$ & $37.0 \mathrm{~b}$ & 29.4 \\
\hline
\end{tabular}

Means with different letters in each column indicate a significant difference at $\mathrm{P}<0.05$ using Duncan multiple range test. 
growing under stressful conditions (Zhang et al. 1996; Ouariti et al. 1997; Wang and Lin 2006; Nouairi et al. 2006b). In various plant species, the increase of MGDG/ DGDG ratio has been detected in response to heavy metals treatment (Zhang et al. 1996; Chaffai et al. 2005; Nouairi et al. 2006b). Nouairi et al. (2006b) confirmed that this high MGDG/DGDG ratio can be correlated with a stress resistance of $B$. juncea in their observation. Skorzynska et al. (1991) showed that the decrease of MGDG/DGDG ratio, might be caused by a high galactolipase activity, which attacks preferentially MGDG. All those changes would mainly concern the photosynthetic apparatus, in which heavy metals, could disturb the architecture of the thylakoidal membranes (Maksymiec et al. 1992; Ouzounidou et al. 1992). Such disorganization in turn affects some light reaction processes, especially those associated with PS II activity (Sun et al. 2010). The PSII complex contains a large number of lipid molecules (Jordan et al. 2001). The biochemical analysis of the lipid content of PSII indicates the presence a number of lipids whose composition is similar to the lipid composition of the thylakoid membrane (Loll et al. 2007). It is well known that in leaves, C18:3 fatty acid is mostly associated with galactolipids (MGDG and DGDG) which account for more than $85 \%$ of thylakoid lipids (Somerville and Browse 1991) and that these two molecules are crucial for photosynthetic activities (Mizusawa and Wada 2012). It was shown that seedlings with reduced amount of MGDG have disrupted photosynthetic membranes. This result shows a complete impairment of photosynthetic ability and the growth (Kobayashi et al. 2007; Aronsson et al. 2008). Similarly, DGDG deficiency results in disorganization in turn affects some light reaction processes, especially those associated with PS I activity that alter the flux of electrons through the photosynthetic electron chain and impair the regulation of distribution of excitation energy between the photosystems (Ivanov et al. 2006). In fact, galactolipids and the tri-unsaturated fatty acid contents of leaves appear to be an important parameter in some aspects of plant physiology such as the efficiency of photosynthesis and the response to stress. It must be kept in mind that modifications in the leaf fatty acid composition may have a direct impact on the plant physiological responses and fitness. Our previous work showed a significant decrease in chlorophyll $a$ and $b$ as $\mathrm{Cd}$ concentration in the treatment medium increases (Elloumi et al. 2007). Accordingly, the reduction in Chl $b$ varied proportionally with $\mathrm{Cd}$ supply, the reduction in $\mathrm{Chl}$ $a$ was significantly more affected by 100 and $150 \mu \mathrm{M} \mathrm{Cd}$ than by 25 and $50 \mu \mathrm{M} \mathrm{Cd}$.

The two other types of lipids investigated here, phospholipids and neutral lipids, behave similarly to the galactolipids. These components are more affected in roots than in leaves of almond plants treated with $\mathrm{Cd}$. This trend is detected in others species such as Silene cucubalus grown under toxic concentration of $\mathrm{Cu}$ (De Vos et al. 1993) and tomato plants treated with either $\mathrm{Cd}$ or $\mathrm{Cu}$ (Ouariti et al. 1997). In fact the decline in the polar lipid concentrations (galactolipids and phospholipids) could be associated with losses in intracellular membranes (Djebali et al. 2002). These findings indicate a decrease in the size and number of chloroplasts. The decrease in the phospholipid levels of the root cell membranes will probably have profound effects on ATPase activity (Kennedy and Gonsalves 1989) and permeability (De Vos and Schat 1991). The degree of fatty acid unsaturation is important to maintain the membrane fluidity and to provide the appropriate environment for membrane functions ( $\mathrm{Xu}$ and Beardall 1997). Our data indicate that toxic level of $\mathrm{Cd}$ used leads to a decrease in concentration of unsaturated fatty acids and to an increase in that of saturated ones in phospholipid classes.

The quantitative and qualitative loss in lipids of treated almond plants suggests that $\mathrm{Cd}$ induces disturbance of the membrane lipid. Among these effects, the activity of lipoxygenase was enhanced (Clijsters et al. 1991; Somashekaraiah et al. 1992). This is responsible for catalysing lipid peroxidation by using unsaturated fatty acids as substrates. Furthermore, the products of the lipoxygenase reaction such as peroxy and hydroxyl radicals, are reactive and can result in further membrane lipid deterioration, and can also affect other macromolecules in the cells (De Vos and Schat 1991; Stadman 1993). Heavy metals are also involved in the production of activated oxygen species that actively induce peroxidation of membrane lipids (Halliwel and Gutteridge 1984). In fact, it is possible to suppose that a decrease of enzymic free radical scavengers caused by heavy metal may also contribute to the shift in the balance of free radical metabolism towards accumulation, leading to breakdown of membrane lipids.

\section{Conclusions}

Our results show that the changes found in total fatty acids, in the profiles of individual polar lipids, and in the unsaturation levels suggest that membrane structure and function might be altered by $\mathrm{Cd}$ stress. Consequently, $\mathrm{Cd}$ stress is presumed to affect membrane fluidity and permeability by producing an irreversible damage to cell functioning. It should be pointed out that these changes are likely to be attributed to toxicity effects of $\mathrm{Cd}$ on membrane lipids, rather than the defense responses. This study clearly showed that the decrease of membrane lipids in almond plants treated with $\mathrm{Cd}$ may be related to an enhanced rate of catabolism and/or to the suppression of lipid biosynthesis.

Competing interests

The authors declare that they have no competing interests. 


\section{Authors' contributions}

Study conception and design: NE, BM and FB. Acquisition and analysis of data: NE. Interpretation of data: NE and BM. Drafting of manuscript: NE and FB. MZ, LC and CJ participated in the statistical analysis. All authors read and approved the final manuscript.

\section{Acknowledgments}

Support from the Laboratory of Bioactive substances Biotechnology Centre of Borj Cedria (CBBC) is gratefully acknowledged. We wish to express our appreciation to Drs Amor Belila and Thouraya chahed for their collaboration.

\begin{abstract}
Author details
${ }^{1}$ Laboratory of Water, Energy and Environment, Sfax University, Higher Institute of Biotechnology of Sfax, Sfax, Tunisia. ${ }^{2}$ Laboratory of Environment and Biology of Arid Area, Department of Life Sciences, Faculty of Sciences of Sfax, Sfax, Tunisia. ${ }^{3}$ Laboratory of Water, Energy and Environment, Sfax University, ENIS, Sfax, Sfax, Tunisia. ${ }^{4}$ Laboratory of Substances Bioactives, Centre de Biotechnologie de Borj Cedria (CBBC), 1050 Hammam-Lif, Tunisia.
\end{abstract}

Received: 28 March 2013 Accepted: 11 February 2014

\section{Published online: 02 August 2014}

\section{References}

Aidi Wannes W, Mhamdi B, Marzouk B (2009) Variations in essential oil and fatty acid composition during Myrtus communis var. italica fruit maturation. Food Chem 112:621-626

Aronsson H, Schöttler MA, Kelly AA, Sundqvist C, Dörmann P, Karim S, Jarvis P (2008) Monogalactosyldiacylglycerol deficiency in Arabidopsis affects pigment composition in the prolamellar body and impairs thylakoid membrane energization and photoprotection in leaves. Plant Physiol 148:580-592

Attila H, Sára E, Tibor J, Erika T, Gábor H, Dénes D (2004) Transgenic tobacco plants overproducing alfalfa aldose/aldehyde reductase show higher tolerance to low temperature and cadmium stress. Plant Sci 166:1329-1333

Ben Ammar W, Nouairi I, Tray B, Zarrouk M, Jemal F, Ghorbel MH (2005) Effets du cadmium sur l'accumulation ionique et les teneurs en lipides dans les feuilles de tomate (Lycopersicon esculentum). J Soc Biol 199:157-163

Ben Youssef N, Nouairi I, Ben Temime S, Taamalli W, Zarrouk M, Ghorbel MH, Ben Miled Daoud D (2005) Effets du cadmium sur le métabolisme des lipides de plantules de colza (Brassica napus L.). C R Biol 328:745-757

Bligh EG, Dyer WJ (1959) A rapid method of total lipid extraction and purification. Can J Biochem Physiol 37:911-917

Brenner RR (1984) Effect of unsaturated acids on membrane structure and enzyme kinetics. Prog Lipid Res 23:69-96

Cecchi G, Biasini S, Castano J (1985) Méthanolyse rapide des huiles en solvants. Note Lab Rev Franc Corps Gras 4:163-164

Certık M, Breierova E, Jursıkova P (2005) Effect of cadmium on lipid composition of Aureobasidium pullulans grown with added extracellular polysaccharides. Int Biodeter Biodegr 55:195-202

Chaffai R, Marzouk B, El Ferjani E (2005) Aluminum mediates compositional alterations of polar lipid classes in maize seedlings. Phytochemistry 66:1903-1912

Chaoui A, Mazhoudi S, Ghorbal MH, El Ferjani E (1997) Cadmium and zinc induction of lipid peroxidation and effects on antioxidant enzyme activities in bean (Phaseolus vulgaris L.). Plant Sci 127:139-147

Clijsters H, Van Assche F, Gora L (1991) Physiological responses of higher plants to soil contamination with metals. In: Rozema J, Verkleij JAC (eds) Ecological Responses to Environmental Stresses. Kluwer Academic Publishers, Netherlands, pp 32-39

Cobbett C, Goldsbrough P (2002) Phytochelatins and metallothioneins: roles in heavy metal detoxification and homeostasis. Annu Rev Plant Physiol Plant Mol Biol 53:159-182

Das P, Samantaray S, Rout GR (1997) Studies on cadmium toxicity in plants: a review. Environ Pollut 98:29-36

De Vos CHR, Schat H (1991) Free radicals and heavy metal tolerance, in Ecological responses to environmental stresses. In: Rozema J, Verkleijv JAC (eds) Ecological Responses to Environmental Stresses. Kluwer Academic Publishers, Netherlands, pp 22-33

De Vos CHR, Ten Boukum WM, Vooijs R, Schat H, De Kok LJ (1993) Effect of copper on fatty acid composition and peroxidation of lipids in the roots of copper tolerant and sensitive Silene cucbalus. Plant Physiol Biochem 31:151-158
Di Toppi LS, Gabbrielli R (1999) Response to cadmium in higher plants. Environ Exp Bot 41:105-130

Djebali W, Chaïbi W, Ghorbel MH (2002) Croissance, activité peroxydasique et modifications ultrastructurales induites par le cadmium dans la racine de tomate. Can J Bot 80:942-953

Djebali W, Zarrouk M, Brouquisse R, El Kahoui S, Limam F, Ghorbel MH, Chaïbi W (2005) Ultrastructure and lipid alterations induced by cadmium in tomato (Lycopersicon esculentum) chloroplast membranes. Plant Biol 7:258-268

Elloumi N, Ben Abdallah F, Rhouman A, Ben Rwina B, Mezghani I, Boukhris M (2007) Cadmium-induced growth inhibition and alteration of biochemical parameters in almond seedlings grown in solution culture. Acta Physiol Plant 29:57-62

Hall $J$ (2002) Cellular mechanisms for heavy metal detoxification and tolerance. J Exp Bot 53:1-11

Halliwel B, Gutteridge JM (1984) Oxygen toxicity, oxygen radicals, transition metals and disease. Biochem J 219:1-14

Hewitt EJ (1966) Sand and water culture methods used in the study of plant nutrition. GAB Tech Gommun 22:431-432

Ivanov AG, Hendrickso L, Krol M, Selstam E, Oquis G, Hurry V, Huner NPA (2006) Digalactosyl-diacylglycerol deficiency impairs the capacity for photosynthetic intersystem electron transport and state transitions in Arabidopsis thaliana due to photosystem I acceptor-side limitations. Plant Cell Physiol 47:1146-1157

Jemal F, Zarrouk M, Ghorbal MH (2000) Effect of cadmium on lipid composition of pepper. Biochem Soc T 28:907-910

Jordan P, Fromme P, Witt HT, Klukas O, Saenger W, Krauss N (2001) Threedimensional structure of cyanobacterial photosystem I at $2.5 \mathrm{~A}$ resolution. Nature 411:909-917

Kennedy CD, Gonsalves FAN (1989) The action of divalent Zn, Cd, Hg, Cu and Pb ions on the ATPase activity of plasma membrane fraction isolated from roots of Zea mays. Plant Soil 117:167-175

Kobayashi K, Kondo M, Fukuda H, Nishimura M, Ohta H (2007) Galactolipid synthesis in chloroplast inner envelope is essential for proper thylakoid biogenesis, photosynthesis, and embryogenesis. Proc Natl Acad Sci 104:17216-17221

Krantev A, Yordanova R, Janda T, Szalai G, Popova L (2008) Treatment with salicylic acid decreases the effect of cadmium on photosynthesis in maize plants. J Plant Physiol 165:920-931

Le Guédard M, Schraauwers B, Larrieu I, Bessoule JJ (2008) Development of a biomarker for metal bioavailability: the lettuce fatty acid composition. Environ Toxicol Chem 27:1147-1151

Lepage M (1967) Identification and composition of turnip root lipids. Lipids 2:244-250

Loll B, Kern J, Seanger W, Zouni A, Biesiadka J (2007) Lipids in photosystem II: Interactions with protein and cofactors. Biochim Biophys Acta 1767:509-519

Ma JF, Ueno D, Zhao FJ, McGrath SP (2005) Subcellular localisation of Cd and Zn in the leaves of a Cd-hyperaccumulating ecotype of Thlaspi caerulescens. Planta 220:731-736

Maksymiec W, Russa R, Urbanik-Sypniewska T, Baszynski T (1992) Changes in acyl lipid and fatty acid composition in thylakoids of copper non-tolerant spinach exposed to excess copper. J Plant Physiol 140:52-55

Martin CE, Hiramitsu K, Kitajima Y, Nozawa Y, Skriver L, Thompson GA (1976) Molecular control of membrane properties during temperature acclimation. Fatty acid desaturase regulation of membrane fluidity in acclimating Tetrahymena cells. Biochemistry 15:5218-5227

Meharg AA (1993) The role of the plasmalemma in metal tolerance in angiosperms. Physiol Plantarum 88:191-198

Mizusawa N, Wada H (2012) The role of lipids in photosystem II. Biochim Biophys Acta (BBA)- Bioenergetics 1817:194-208

Mohamed AA, Castagna A, Ranieri A, Sanità di Toppi L (2012) Cadmium tolerance in Brassica juncea roots and shoots is affected by antioxidant status and phytochelatin biosynthesis. Plant Physiol Biochem 57:15-22

Nouairi I, Ghnaya T, Ben Youssef N, Zarrouk M, Ghorbel MH (2006a) Changes in content and fatty acid profiles of total lipids of two halophytes: Sesuvium portulacastrum and Mesembryanthemum crystallinum under cadmium stress. J Plant Physiol 163:1198-1202

Nouairi I, Ben Ammar W, Ben Youssef N, Ben Miled Daoud D, Ghorbel MH, Zarrouk M (2006b) Comparative study of cadmium effects on membrane lipid composition of Brassica juncea and Brassica napus leaves. Plant Sci 130:165-170

Nussbaum S, Schmutz D, Brunold C (1988) Regulation of assimilatory sulfate reduction by cadmium in Zea mays L. Plant Physiol 88:1407-1410 
Ouariti O, Boussama N, Zarrouk M, Cherif A, Ghorbal MH (1997) Cadmium- and copper-induced changes in tomato membrane lipids. Phytochemistry 45:1343-1350

Ouzounidou G, Eleftheriou EP, Karataglis S (1992) Ecophysiological and ultrastructural effects of copper in Thlaspi ochroleucum (Cruciferae). Can J Bot 70:947-957

Robinson B, Russell C, Hedley M, Clothier B (2001) Cadmium adsorption by rhizobacteria: implications for New Zealand pastureland. Agr Ecosyst Environ 87:315-321

Schützendübel A, Schwanz P, Teichmann T, Gross K, Langenfeld-Heyser R, Godbold DL, Polle A (2001) Cadmium-induced changes in antioxidative systems, hydrogen peroxide content, and differentiation in scots pine roots. Plant Physiol 127:887-898

Shukla UC, Singh J, Joshi PC, Kakkar P (2003) Effect of bioaccumulation of cadmium on biomass productivity, essential trace elements, chlorophyll biosynthesis, and macromolecules of wheat seedlings. Biol Trace Elem Res 92:257-273

Skorzynska E, Urbanik-Sypniewska T, Russa R, Baszynski T (1991) Galactolipase activity of chloroplasts in cadmium-treated runner bean plants. J Plant Physiol 138:454-459

Sobkowiak R, Rymer K, Ruciniska R, Deckert J (2004) Cadmium- induced changes in antioxidant enzyme in suspension culture of soybean cells. Acta Biochim Pol 51:219-222

Somashekaraiah BV, Padmaja K, Prasad ARK (1992) Phytotoxicity of cadmium ions on germinating seedlings of mung bean (Phaseolus vulgaris): Involvement of lipid peroxides in chlorphyll degradation. Physiol Plantarum 85:85-89

Somerville C, Browse J (1991) Plant lipids: metabolism, mutants, and membranes. Science 252:80-87

Stadman ER (1993) Oxidation of free amino acids and amino acid residues in proteins by radiolysis and by metal-catalyzed reactions. Annu Rev Biochem 62:797-821

Sun YL, Li F, Su N, Sun XL, Zhao SJ, Meng QW (2010) The increase in unsaturation of fatty acids of phosphatidylglycerol in thylakoid membrane enhanced salt tolerance in tomato. Photosynthetica 48:400-408

Vassilev A, Lidon F, Scotti P, Da Graca M, Yordanov I (2004) Cadmium-induced changes in chloroplast lipids and photosystem activities in barley plants. Biol Plantarum 48:153-156

Velikova V, Tsonev T, Loreto F, Centritto M (2011) Changes in photosynthesis, mesophyll conductance to $\mathrm{CO}_{2}$, and isoprenoid emissions in Populus nigra plants exposed to excess nickel. Environ Pollut 159:1058-1066

Verdoni N, Mench M, Cassagne C, Bessoule JJ (2001) Fatty acid composition of tomato leaves as biomarkers of metal-contaminated soils. Environ Toxicol Chem 20:382-388

Verkleij JAC, Schat H (1990) Mechanisms of metal tolerance in higher plants. In: Shaw AJ (ed) Heavy Metal Tolerance in Plants: Evolutionary Aspects. CRC Press, FL, pp 179-193

Wang SY, Lin HS (2006) Effect of plant growth temperature on membrane lipids in strawberry (Fragaria $x$ ananassa Duch.). Sci Hortic Amsterdam 108:35-42

Williams JP, Khan MU, Mitchell K (1983) Galactolipid biosynthesis in leaves of 16:3 and 18:3-plants. In: Thomson WW, Mudd JB, Gibbs M (eds) Biosynthesis and function of plant lipids. American Society of Plant Physiology Symposium in Botany Riverside, California, pp 28-39

Xu XQ, Beardall J (1997) Effect of salinity on fatty acid composition of a green microalga from an Antarctic hypersaline lake. Phytochemistry 45:655-658

Zhang G, Slaski JJ, Archambault DJ, Taylor GJ (1996) Aluminum-induced alterations in lipid composition of microsomal membranes from an aluminum-resistant and aluminum-sensitive cultivar of Triticum aestivum. Physiol Plantarum 96:683-691

doi:10.1186/s40529-014-0061-7

Cite this article as: Elloumi et al: Effects of cadmium on lipids of almond seedlings (Prunus dulcis). Botanical Studies 2014 55:61.

\section{Submit your manuscript to a SpringerOpen ${ }^{\circ}$ journal and benefit from:}

- Convenient online submission

- Rigorous peer review

- Immediate publication on acceptance

- Open access: articles freely available online

- High visibility within the field

- Retaining the copyright to your article

Submit your next manuscript at $\gg$ springeropen.com 